\title{
New species of Platypalpus (Diptera: Hybotidae) from the Democratic Republic of the Congo
}

\author{
Patrick GROOTAERT $^{1} \&$ Igor SHAMSHEV ${ }^{2}$ \\ ${ }^{1,2}$ Entomology, Royal Belgian Institute of Natural Sciences, Rue Vautier 29, B-1000, Brussels, Belgium. \\ Email: Patrick.Grootaert@naturalsciences.be (corresponding author) \\ ${ }^{2}$ All-Russian Institute of Plant Protection, shosse Podbel'skogo 3, 188620, St. Petersburg, Russia. \\ Temporary address: Royal Belgian Institute of Natural Sciences, Brussels. \\ Email: shamshev@mail.ru \\ ${ }^{1}$ urn:1sid:zoobank.org:author:B80BC556-9087-4D0D-9D69-7FA9BE5779C4 \\ ${ }^{2}$ urn:Isid:zoobank.org:author:569F41CC-EC2B-4CF0-802A-8D7056C72C93
}

\begin{abstract}
Six new species of Platypalpus Macquart, 1827 are described from tropical forest at Yangambi (Democratic Republic of the Congo): Platypalpus bolikoi sp. nov., P. ikoso sp. nov., P. lokonda sp. nov., P. manjano sp. nov., P. saffradi sp. nov. and P. yangambensis sp. nov. All species are photographed and, except for $P$. saffradi sp. nov. known only from females, male terminalia are illustrated for all. A key is provided for the six species of DR Congo. COI barcodes are available for all species at GenBank.
\end{abstract}

Keywords. Afrotropical Region, Diptera, Platypalpus, new species.

Grootaert P. \& Shamshev I. 2014. New species of Platypalpus (Diptera: Hybotidae) from the Democratic Republic of the Congo. European Journal of Taxonomy 103: 1-20. http://dx.doi.org/10.5852/ejt.2014.103

\section{Introduction}

The genus Platypalpus Macquart, 1827 is the largest group of the Hybotidae subfamily Tachydromiinae and one of the most speciose genera of Empidoidea on the whole. Currently about 550 species of Platypalpus are known worldwide but about $75 \%$ of them were described from the Palaearctic and Nearctic regions (Yang et al. 2007). In the Afrotropical Region only 28 species are known. The first species was described by Loew (1858) from South Africa; Becker (1914) described three species from Kenya; Collin (1922) described a single species from the Seychelles; Smith (1967a) described five species from Tanzania and eighteen species from South Africa (Smith 1967b, 1969). Only South African species of Platypalpus have been keyed.

In contrast to the Palaearctic region where Platypalpus is very common and diverse, few Platypalpus species are found in tropical lowland forests in the Afrotropical Region. Having a similar habitat and niche as Elaphropeza Macquart, 1827, Platypalpus probably comes into competition with Elaphropeza that is likely more adapted to tropical conditions. However above $500 \mathrm{~m}$, Platypalpus is more speciesrich and the number of Elaphropeza species drops (Grootaert \& Shamshev 2006). 
The present paper is the result of a short sampling campaign at the end of May and first half of June 2013 in the surroundings of Yangambi (DR Congo, Oriental Province) at an altitude of about $400 \mathrm{~m}$. The collection was made at the beginning of the 'short dry season' and indeed it did not rain at all during the campaign. Collections were made in a patchwork of forest types ranging from garden patches, bamboo, over young forest to mixed primary and monodominant (Gilbertiodendron J.Léonard) forest. The study was in the scope of the PODO project COBIMFO (Congo Basin Integrated Monitoring for Forest Carbon Mitigation and Biodiversity) in which a relation is being sought between carbon fixation and biodiversity. The aim of this project is to get baseline reference data on the Carbon balance and biodiversity in pristine and intervened dense tropical forests of the Congo Basin and to increase our understanding of the relationship between both variables as a function of forest management.

Only thirteen specimens of Platypalpus were found out of a total of about 1600 Tachydromiinae showing how rare Platypalpus is. However, they belong to six species all new for science. Moreover Platypalpus is here reported for the first time from DR Congo.

The present study is also the continuation of a major review of the Hybotidae of DR Congo that was started in 2010 (Grootaert \& Shamshev 2013).

\section{Material and methods}

The holotypes will be housed in the Collections of the Centre de Surveillance de la Biodiversite in Kisangani (DR Congo) as soon as the facilities will be fully operational, but are now temporarily deposited in the Royal Belgian Institute of Natural Sciences, Brussels, Belgium (RBINS). In the descriptions we cite under 'reg.' the register number that is a unique identifier referring to the locality, date and microhabitat. When we cite the holotype we indicate also the MS name or code that was used throughout the description process e.g. 'Plat3' is the third Platypalpus species found in the Congo samples. All specimens were collected by the first author (PG) by sweep netting and are conserved in $70 \%$ ethanol. The specimens from which DNA was extracted are conserved in our tissue collection at RBINS with the cuticular parts still being recognisable. We refer to the barcode of the tube in the tray in which it is conserved: e.g. 'tube AB31515301' stored in tray called 'Congo2'.

The terminology and descriptive format used in the descriptions follow Grootaert \& Shamshev (2012). In describing the sclerites of the thorax the terminology used by previous authors is often indicated in brackets. The scale bar represents $0.1 \mathrm{~mm}$, but this is only an indicative measure because the drawings are projections of structures that are usually not in a horizontal plane.

\section{Abbreviations}

The following abbreviations are used in the illustrations:
$\mathrm{a}=$ apodeme
lc $=$ left cercus
lel $=$ left epandrial lamella
$\mathrm{rc}=$ right cercus
rel $=$ right epandrial lamella
rs $=$ right surstylus.

The species-groups of Platypalpus are according to Grootaert \& Chvála (1992). 


\title{
Results
}

\author{
Class Insecta Linnaeus, 1758 \\ Order Diptera Linnaeus, 1758 \\ Superfamily Empidoidea Latreille, 1804 \\ Family Hybotidae Macquart, 1823 \\ Subfamily Tachydromiinae Meigen, 1822 \\ Genus Platypalpus Macquart, 1827
}

Coryneta Meigen, 1800: 27. Type-species: Musca cursitans Fabricius, 1775, by subsequent designation of Engel (1939: 43). Suppressed by ICZN (1963: 339; Opinion 678).

Platypalpus Macquart, 1827: 92. Type-species: Musca cursitans Fabricius, 1775, by subsequent designation of Westwood (1840: 132).

\section{Platypalpus bolikoi sp. nov. urn:1sid:zoobank.org:act:F1FB7470-9502-4B74-B175-4C76BC47E5F4}

Figs 1-5

\section{Diagnosis}

Small black species of the pallidiventris-cursitans group. One pair of verticals. Postpedicel short, 1.5 times as long as wide. Thorax faintly tomentose on scutum. Legs including all coxae yellow, but mid femur brownish dorsally and hind femur dark brown on apical $2 / 3$, apical half of tarsomere 5 of all legs brownish; large pointed apical spur on mid tibia.

\section{Etymology}

The species is dedicated to Mr. Lola Boliko, who guided the first author in the forest during the expedition in 2013.

\section{Type material}

Holotype $\widehat{\partial}$, DR Congo, Yangambi, 7 Jun. 2013, young forest JEU2 (047’41.77” N 24²9’30.91” E; reg. 33053; leg. P. Grootaert; Plat4); mid leg in tray Entomo 004 in position A2 with barcode AB42406107
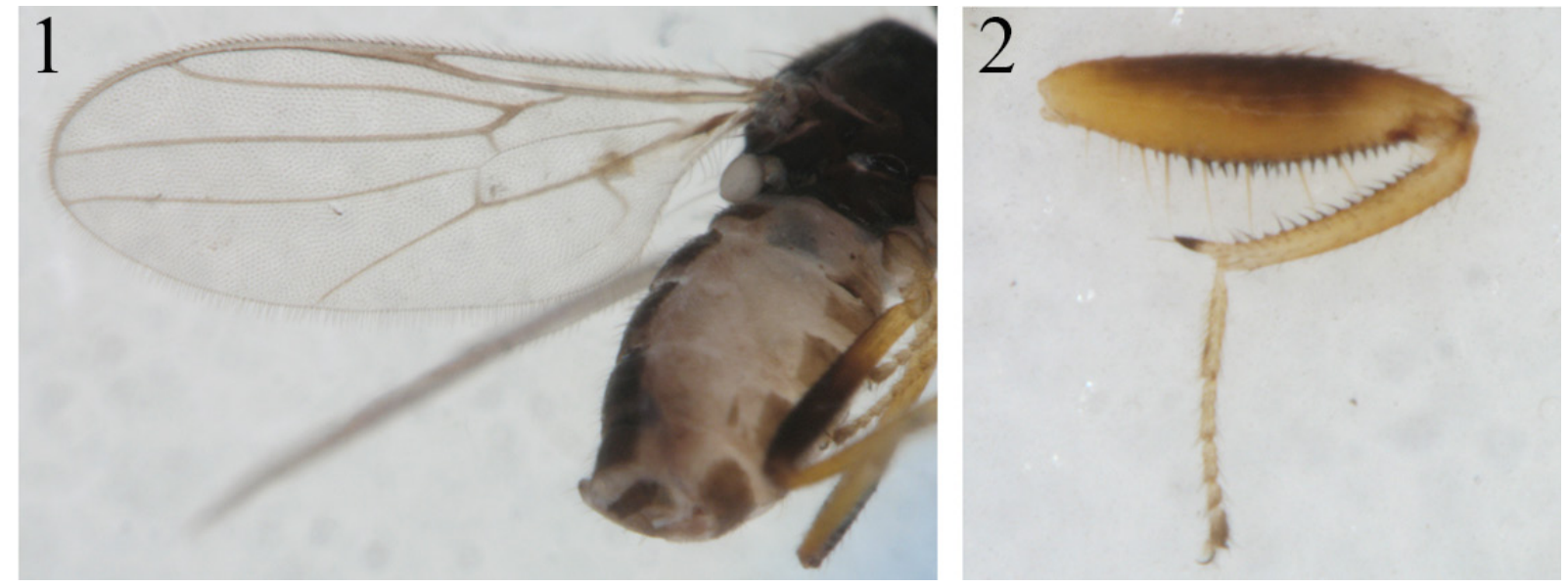

Figs 1-2. Platypalpus bolikoi sp. nov., holotype $\widehat{\jmath}$. 1. Wing, abdomen and hind femur. 2. Mid femur, posterior view. 
was extracted for DNA and the COI barcode can be accessed in GenBank with the accession number: KJ768325.

\section{Description}

\section{Male}

Length. Body $2.0 \mathrm{~mm}$; wing $1.8 \mathrm{~mm}$.

HEAD. Entirely black. Occiput densely greyish pollinose; with 1 pair of long yellow verticals. Ocellar tubercle greyish pollinose, with subequally very short anterior and posterior setae. Frons broad, somewhat broadened toward ocellar tubercle, subshining. Face narrow, greyish pollinose, clypeus subshining. Antenna with scape and pedicel brown, postpedicel and stylus yellowish brown; postpedicel small, ovoid, 1.5 times as long as wide; stylus 1.8 times as long as postpedicel. Proboscis pale yellowish brown, shorter than head is high. Palpus pale yellow, large, elongate ovate, with scattered pale setulae.

THORAX. Black to brown; faintly tomentose, katepisternum (= sternopleuron) shining; bristles yellowish to yellowish brown. Postpronotal lobe large, with 1 long and several minute setae. Mesonotum with 2 notopleurals (anterior seta very short, posterior seta long), 1 moderately long postalar and 4 scutellars (apical pair long, lateral pair short); additionally, notopleuron with several setulae; acrostichals short, sparse, arranged in 2 broad irregular rows; dorsocentrals arranged in 1-2 rows, nearly as long as acrostichals, 1 prescutellar long.

LEGS. Largely reddish yellow, but mid femur brownish dorsally, hind femur dark brown on about apical $2 / 3$, tarsomere 5 of all legs yellowish brown apically. Coxae and trochanters with ordinary yellowish to brownish yellow setae of different lengths. Fore femur thickened; with rows of short anteroventral and posteroventral setae. Fore tibia rather slender, clothed with ordinary setulae. Mid femur very thickened; with double row of black ventral spinules and row of long, yellow posteroventral setae. Mid tibia bearing

\section{3}

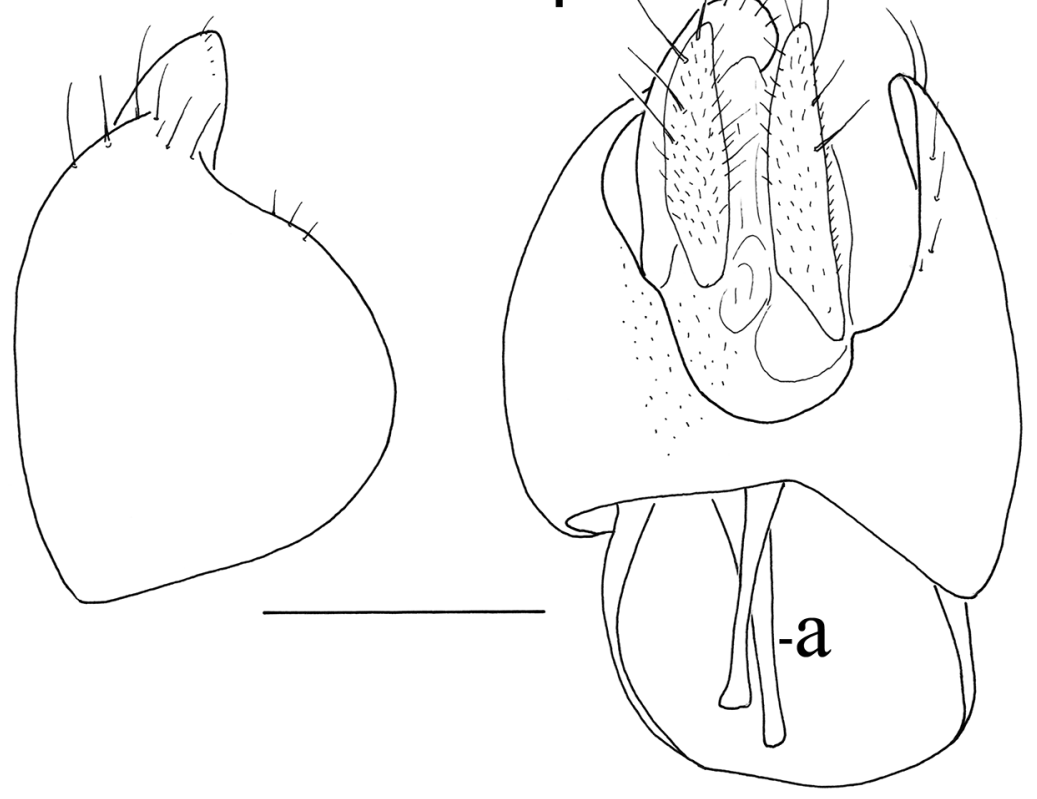

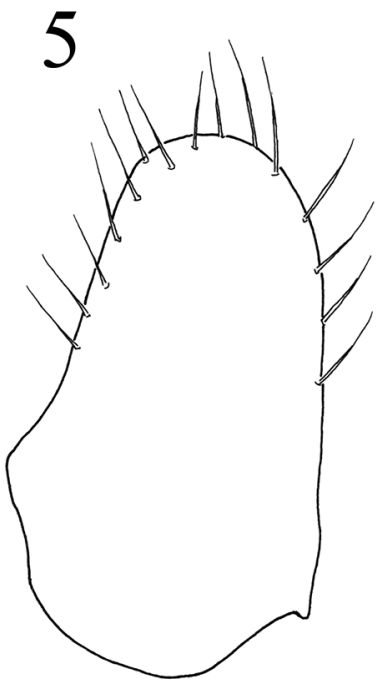

Figs 3-5. Platypalpus bolikoi sp. nov., holotype $ð$. 3. Right epandrial lamella. 4. Epandrium with cerci, dorsal view. 5. Left epandrial lamella. Scale bar $=0.1 \mathrm{~mm}$. 
a row of black ventral spinules; with long pointed largely black apical spur. Hind femur slender, with short anteroventral setae. Hind tibia slender, clothed with ordinary setulae. Tarsi of all legs unmodified.

WING. Hyaline, with brownish veins. One moderately long black costal seta. Veins $R_{4+5}$ and $M_{1+2}$ somewhat convergent just before meeting wing margin. Crossveins $\mathrm{m}-\mathrm{cu}$ and $\mathrm{r}-\mathrm{m}$ separated; cell bm longer and somewhat broader than cell br; Vein $\mathrm{CuA}_{2}$ straight. Anal vein evanescent in apical part and lacking in basal part. Calypter brown, with brown setae. Halter brownish.

АвDомEN. With tergites brownish, subshining, covered with faint very short setae; sternites brownish, with similar setae; segment 8 with several moderately long yellowish brown posteromarginal setae. Terminalia rather small, brown (Figs 3-5). Both cerci digitiform, equally long, shorter than right epandrial lamella. Right and left epandrial lamella equally long, set with unmodified setae. Only short setae of left border of left epandrial lamella.

\section{Female}

Unknown.

\section{Comparison}

In the key of Smith (1969) the new species runs to P. vicina Smith, 1969 that was described from South Africa. In the latter species the fore femur is darkened above while in P. bolikoi sp. nov. the fore femur is entirely yellow. In P. vicina the mid and hind coxae are darkened. Here they are yellow. Platypalpus soror Smith, 1969 has a black proboscis and yellow halteres. In the new species the proboscis is pale and halteres are brown.

\section{Distribution}

DR Congo.

$$
\begin{aligned}
& \text { Platypalpus ikoso sp. nov. } \\
& \text { urn:1sid:zoobank.org:act:9245014C-ECB6-4DD1-B1EA-8990AF64C6BD }
\end{aligned}
$$

Figs $6-13$

\section{Diagnosis}

A medium-sized species of the albiseta-group. Postpedicel 5.3 times as long as wide; stylus white, 1.6 times as long as postpedicel. Legs reddish-yellow. Mid femur with a short flattened apical spur.

\section{Etymology}

The specific epithet 'ikoso' means fly or mosquito in Tumburu, the local language spoken at Yangambi.

\section{Type material}

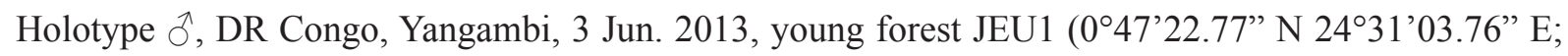
reg. 33034; leg. P. Grootaert; MS name Plat3); mid leg in tray Entomo 004 position A1 with barcode AB42406101 was extracted for DNA and COI barcode is available in GenBank with accession number: KJ768325.

\section{Description}

\section{Male}

LeNGTH. Body $3.7 \mathrm{~mm}$; wing $2.9 \mathrm{~mm}$. 
HEAD. Entirely black. Occiput densely greyish pollinose; with 1 pair of long black verticals. Ocellar tubercle greyish pollinose, with 2 black, moderately long anterior and 2 very short posterior setae. Frons narrow, somewhat broadened toward ocellar tubercle, above antennae slightly broader than anterior ocellus, greyish pollinose. Face narrow, on middle as broad as anterior ocellus, somewhat broader below antennae and on lower part, greyish pollinose, clypeus subshining. Antenna with scape, pedicel and postpedicel brown; postpedicel conical, long, 5.3 times as long as wide; stylus white, long pubescent, 1.6 times as long as postpedicel. Proboscis brownish yellow, rather long, somewhat shorter than head is high. Palpus brownish yellow, small, ovate, with scattered dark setulae.

THorax. (Fig. 6). With mesonotum brown, otherwise reddish brown; scutum shining (except prescutellar depression), katepisternum (= sternopleuron) with small shining spot, otherwise thorax faintly tomentose;
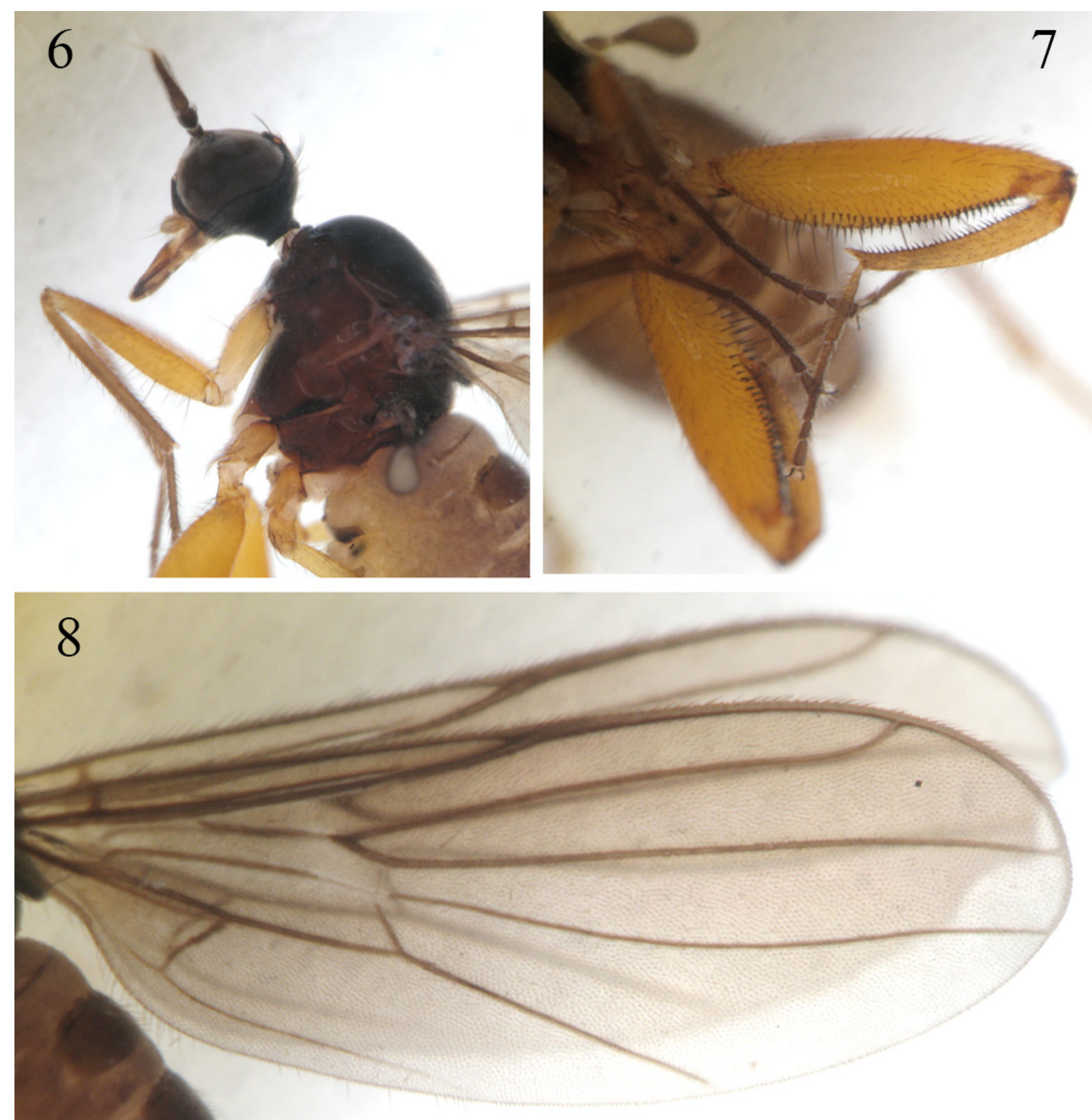

Figs 6-8. Platypalpus ikoso sp. nov., holotype $\lesssim$. 6. Head, thorax, lateral view. 7. Mid legs, anterior view. 8. Wing. 
bristles black. Postpronotal lobe small, elongate, narrow, with several minute setulae. Mesonotum with 2 notopleurals (anterior seta very short, posterior seta moderately long), 1 moderately long postalar and 4 scutellars (apical pair long and cruciate, lateral pair very short); additionally, notopleuron with several setulae; acrostichals minute, scattered, arranged in 2 irregular rows; dorsocentrals arranged in 1 row, nearly as long as acrostichals, 2 prescutellars long.

LEGs. Largely reddish yellow, fore and hind tibiae, entire fore tarsus, apical tarsomeres of mid and hind tarsi rather brownish yellow. Coxae and trochanters with ordinary yellowish to brownish yellow setae of different lengths. Fore femur slender; with rows of thin anteroventral and posteroventral setae shorter closer to apex, the latter including 2 longer brownish setae closer to base. Fore tibia slender, clothed with ordinary setulae. Mid femur (Fig. 7) very thickened, long; with double row of black ventral spinules and row of long, black posteroventral setae. Mid tibia bearing a row of black ventral spinules; with short flattened apical spur. Hind femur slender, with short anteroventral setae. Hind tibia slender, clothed with ordinary setulae. Tarsi of all legs unmodified.

WING. (Fig. 8). Uniformly brownish infuscate, with brownish veins. One moderately long costal seta. Veins $\mathrm{R}_{4+5}$ and $\mathrm{M}_{1+2}$ somewhat convergent just before meeting wing margin. Crossveins $\mathrm{m}-\mathrm{cu}$ and $\mathrm{r}-\mathrm{m}$ contiguous; cell bm longer and somewhat broader than cell br; Vein $\mathrm{Cu}$ not reaching wing border. Vein $\mathrm{CuA}_{2}$ somewhat sinuate. Anal vein distinct in apical part and evanescent in basal part. Calypter brown, with brown setae. Halter with stem blackish brown, knob brown.

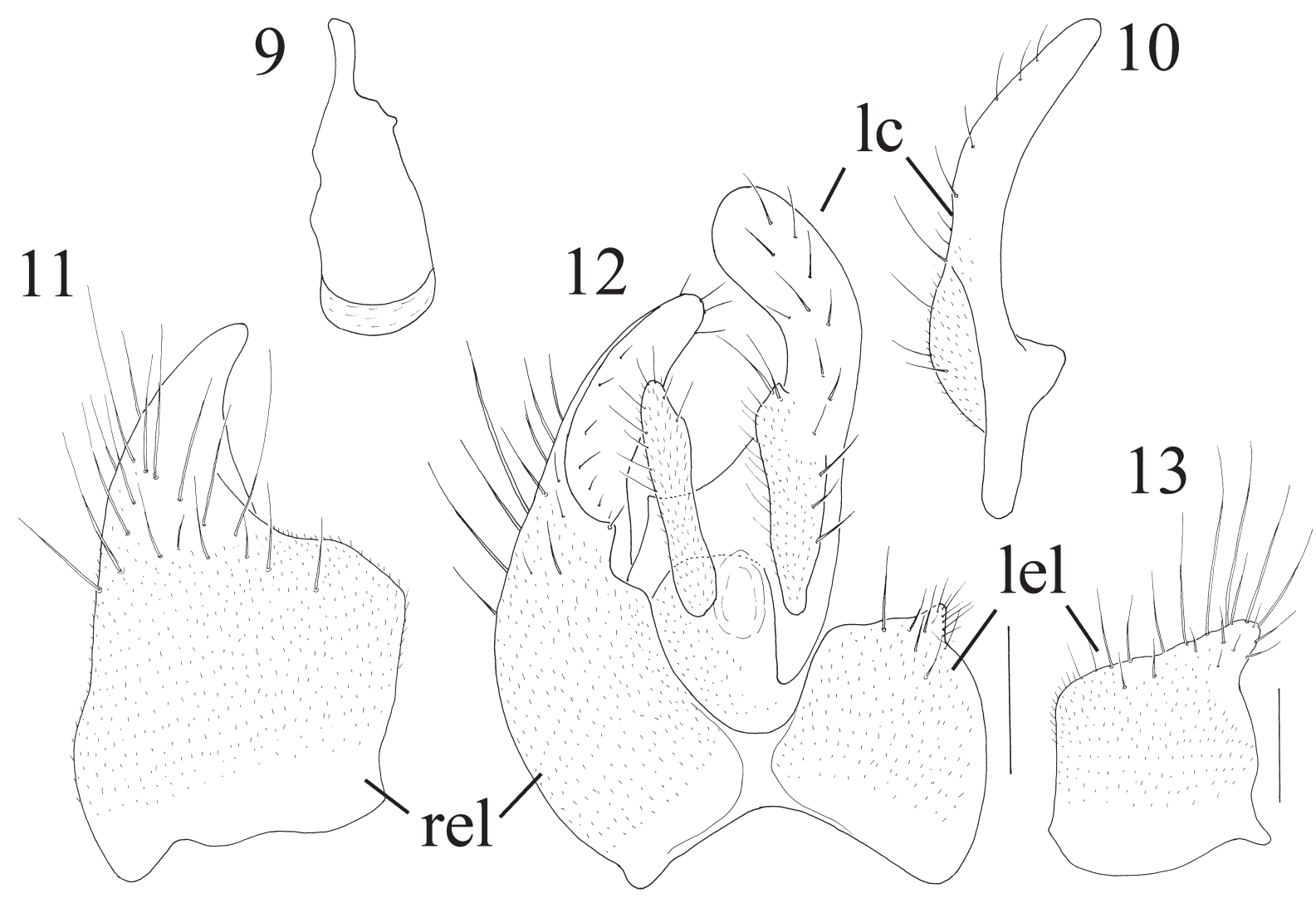

Figs 9-13. Platypalpus ikoso sp. nov., holotype $\widehat{\jmath}$. 9. Hypandrium. 10. Left cercus. 11. Right epandrial lamella. 12. Epandrium with cerci, dorsal view. 13. Left epandrial lamella. Scale bars $=0.1 \mathrm{~mm}$. 
ABDOMEN. With tergites brownish, subshining, covered with faint very short setae; sternites brownish, with similar setae; segment 8 with several long black posteromarginal setae. Terminalia (Figs 9-13) rather small, brown. Left cercus (Figs 10,12) much longer than right cercus. Left epandrial lamella (Figs 12,13) much smaller than right epandrial lamella (Figs 11, 12). Apex of left epandrial lamella with some long setae.

\section{Female}

Unknown.

\section{Comparison}

In the key of Smith (1969) Platypalpus ikoso sp. nov. runs to P. inermifemur Smith, 1969 and P. ngomensis Smith, 1969 both described from South Africa. In P. inermifemur the ratio of second and third sections of vein $\mathrm{Cu}$ (fifth vein sensu Smith 1969) is $3: 3.5$ and the hind femur is without distinct anteroventral setae. In P. ngomensis the ratio of second and third section of vein $\mathrm{Cu}$ is $2: 3.5$ and the hind femur bears short, but distinct anteroventral setae. In $P$. ikoso sp. nov. the apical section of vein $\mathrm{Cu}$ is twice as long as the second section being 2:4, which is comparable to P. ngomensis. The femur bears distinct anteroventral setae that are half as long as femur is wide. In P. ngomensis the left epandrial lamella is about as long as the right epandrial lamella. In P. ikoso sp. nov. the left lamella is very short (Fig. 12). In addition vein $\mathrm{Cu}$ does not reach the wing border in P. ikoso sp. nov. and P. ngomensis, but it does in P. inermifemur.

\section{Distribution}

DR Congo.

$$
\begin{aligned}
& \text { Platypalpus lokonda sp. nov. } \\
& \text { urn:lsid:zoobank.org:act:9D8BC13D-DB91-423E-8A20-AB96DB911E61 }
\end{aligned}
$$

Figs 14-20

\section{Diagnosis}

A medium-sized species of the albiseta-group. One pair of long vertical bristles. Antenna black, postpedicel nearly 4 times as long as wide; with white stylus, almost 2.5 times as long as postpedicel. Mesonotum dark brown; pleura brown. Mid tibia with short pointed apical spur.

\section{Etymology}

The specific epithet 'lokonda' means forest in Tumburu language, the language spoken at Yangambi.

\section{Type material}

\section{Holotype}

§, DR Congo, Yangambi, 27 May 2013, primary mixed forest $\left(0^{\circ} 48^{\prime} 04.69^{\prime \prime} \mathrm{N} 24^{\circ} 31^{\prime} 37.87^{\prime \prime} \mathrm{E}\right.$; reg. 33011; leg. P. Grootaert; MS name Plat2); mid leg in tray Entomo 004 at position A6 with barcode AB42406131; COI barcode available in GenBank with accession number: KJ768328.

\section{Paratype}

1 $\widehat{\partial}$, DR Congo, Yangambi, 31 May 2013, monodominant Gilbertiodendron forest GIL3, sweeping (047'46.09” N 2429'53.46” E; reg. 33025; leg. P. Grootaert); in tray Entomo 001 at position E2 with barcode AB48937147; COI barcode available in GenBank with accession number: KJ768327.

\section{Description}

\section{Male}

LENGTH. Body $2.5 \mathrm{~mm}$; wing $2.2 \mathrm{~mm}$. 
HEAD. Entirely black. Occiput densely greyish pollinose; with 1 pair of long black verticals. Ocellar tubercle greyish pollinose, with long anterior and minute posterior setae. Frons narrow, somewhat broadened toward ocellar tubercle, greyish pollinose. Face very narrow, somewhat broadened below, greyish pollinose, clypeus subshining. Antenna (Fig. 15) with scape, pedicel and postpedicel brown; postpedicel conical, long, 3.7 times as long as wide; stylus white, densely pubescent, 2.4 times as long as postpedicel. Proboscis brownish yellow, shorter than head is high. Palpus pale yellow, short, elongate ovate, with scattered pale setulae.

Thorax. (Figs 14, 15). With mesonotum dark brown, otherwise yellowish brown; faintly tomentose, scutum shining anteriorly; bristles black. Pleura also finely tomentose including katepisternum (= sternopleuron). Postpronotal lobe small, narrow, with several minute setulae. Mesonotum with 2 notopleurals (anterior seta very short, posterior seta long), 1 moderately long postalar and 4 scutellars (apical pair long, cruciate, lateral pair very short); additionally, notopleuron with several setulae; acrostichals biserial, very short, few setae on anterior part of scutum; dorsocentrals uniserial, very short, 2 prescutellar pairs (anterior setae proclinate, posterior setae inclinate) long.

Legs. Yellow. Coxae and trochanters with ordinary yellowish to brownish yellow setae of different lengths. Fore femur slender; with rows of anteroventral and posteroventral yellowish setae longer on basal part. Fore tibia slender, clothed with ordinary setulae. Mid femur (Fig. 17) very thickened; with double row of black ventral spinules and row of long, brownish yellow posteroventral setae. Mid tibia bearing a row of black ventral spinules; with short flattened apical spur. Hind femur slender, with short anteroventral setae. Hind tibia slender, clothed with ordinary setulae. Tarsi of all legs unmodified.
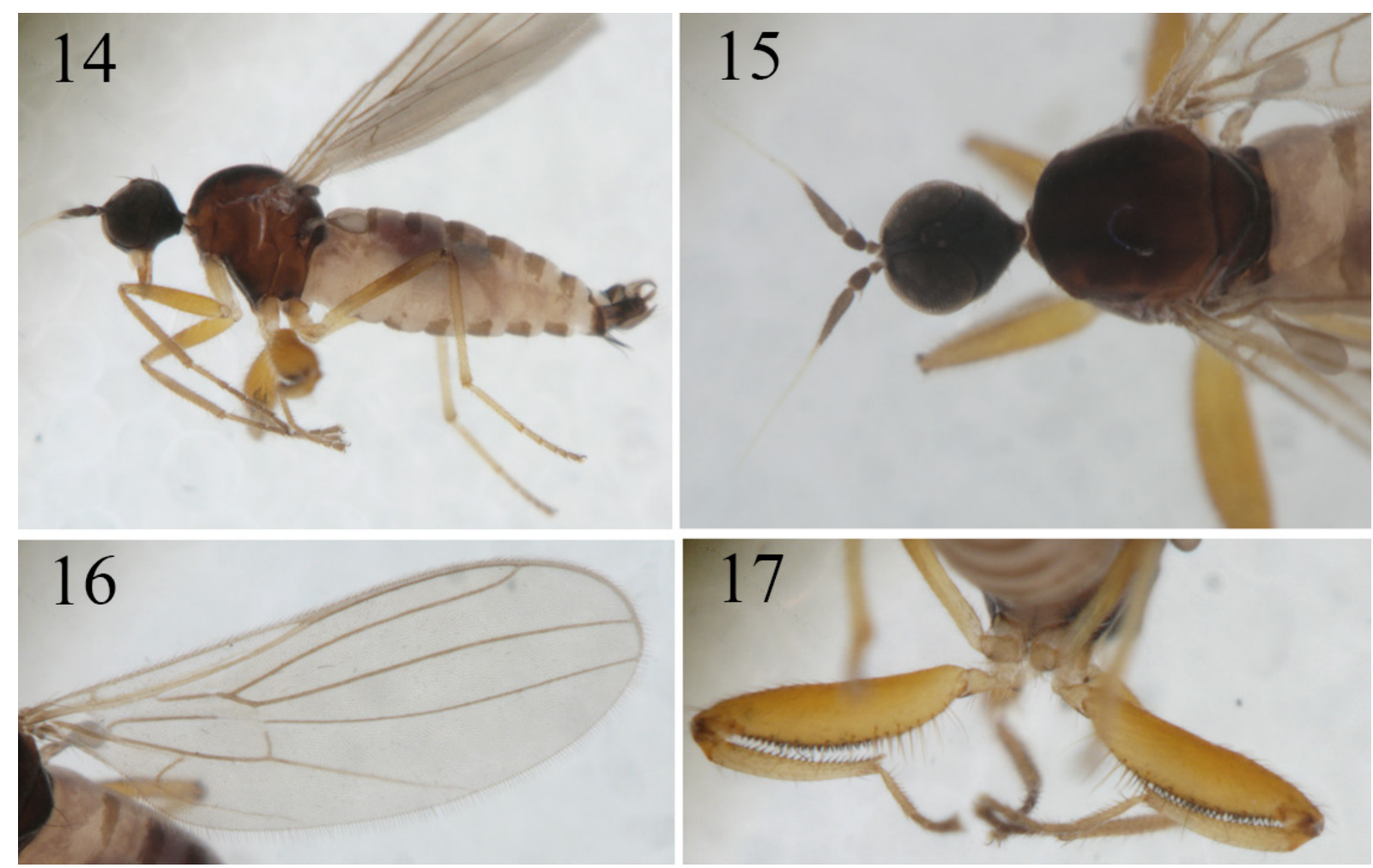

Figs 14-17. Platypalpus lokonda sp. nov., paratype $\lesssim$. 14. Habitus, lateral view. 15. Head and thorax, dorsal view. 16. Wing. 17. Mid legs, posterior view. 
WiNG. (Fig. 16). Faintly infuscate, with brownish veins. One moderately long costal seta. Veins $\mathrm{R}_{4+5}$ and $\mathrm{M}_{1+2}$ convergent just before meeting wing margin. Crossveins $\mathrm{m}-\mathrm{cu}$ and $\mathrm{r}-\mathrm{m}$ contiguous; cell bm somewhat longer and broader than cell br. Vein $\mathrm{CuA}_{2}$ sinuate. Anal vein distinct in apical part and evanescent in basal part. Calypter brown, with brown setae. Halter brownish.

AвDомEN. With tergites brownish, subshining, covered with faint very short setae; sternites brownish, with similar setae; segment 8 with several long black posteromarginal setae. Terminalia (Figs 14, 18-20) small, brown. Left cercus much longer than right cercus, both widely separated. Cerci clothed by unmodified hairs and setae. Left epandrial lamella (Figs 19,20) much shorter than right epandrial lamella (Figs 18, 19). Left epandrial lamella with two long apical setae.

\section{Female}

Unknown.

\section{Comparison}

Platypalpus lokonda sp. nov. is very closely related to P. ngomensis Smith, 1969 described from Natal, South Africa. It differs in having brown prothoracic sterna and propleura which are yellow in $P$. ngomensis. In the latter species, the left epandrial lamella is about as long as the right epandrial lamella, in $P$. lokonda sp. nov., the left lamella is very short.

\section{Distribution}

\section{DR Congo.}

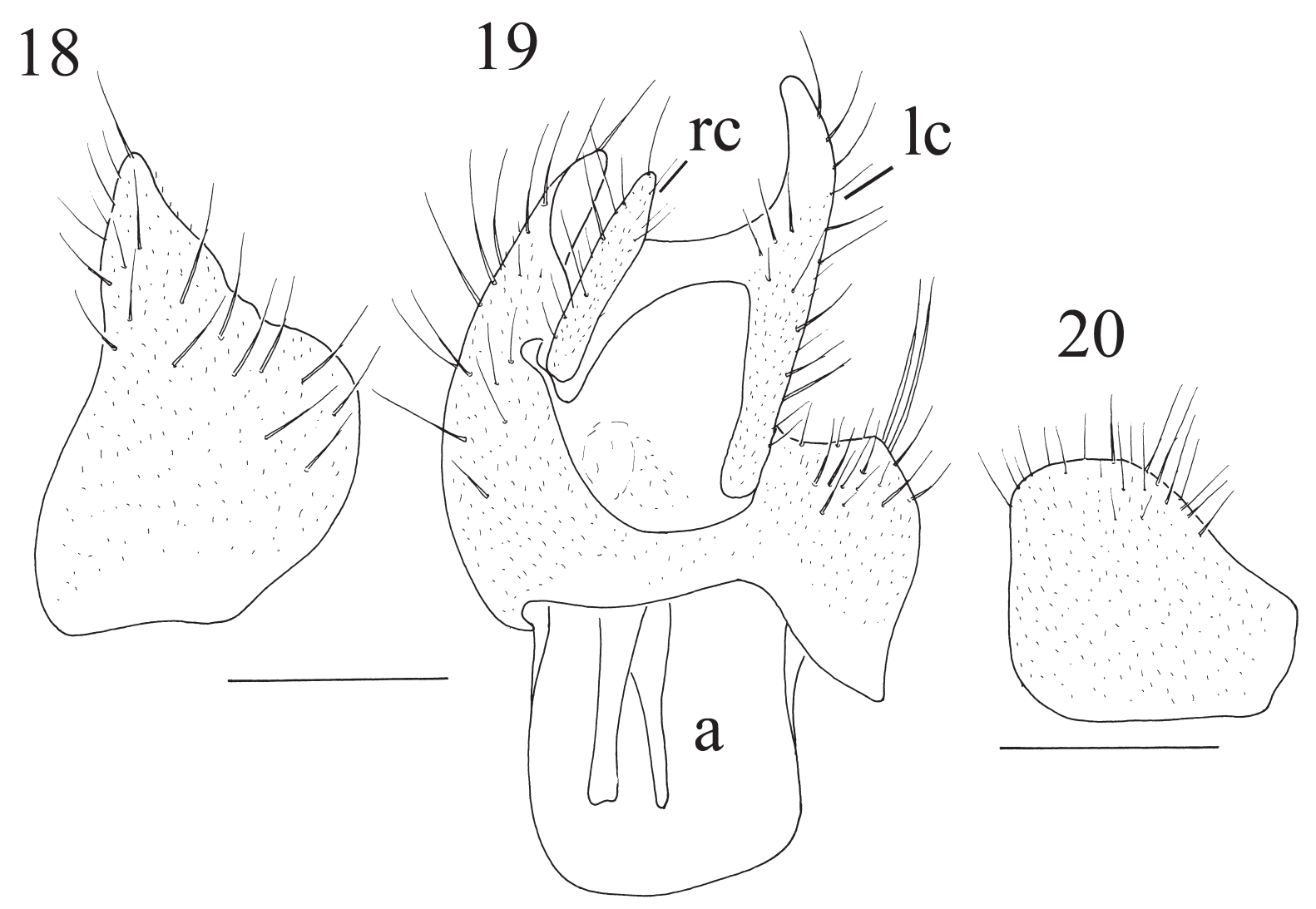

Figs 18-20. Platypalpus lokonda sp. nov., holotype $\widehat{\jmath}$. 18. Right epandrial lamella. 19. Epandrium with cerci, dorsal view. 20. Left epandrial lamella. Scale bars $=0.1 \mathrm{~mm}$. 


\section{Platypalpus manjano sp. nov. \\ urn:1sid:zoobank.org:act:85EE94E0-1364-4011-834E-2E421CB4E83A}

Figs $21-27$

\section{Diagnosis}

A medium-sized yellow species of the albiseta-group. Postpedicel brown, a little more than 5 times as long as wide; stylus white, about as long as postpedicel. Mid tibia with short yellow apical sharp spur, shorter than tibia is wide.

\section{Etymology}

The word 'manjano' means yellow in Turumbu, language that is spoken in Yangambi. It refers to the yellow body colour of the new species.

\section{Type material}

Holotype đ̊ , DR Congo, Yangambi, 27 May 2013, primary mixed forest $\left(0^{\circ} 48^{\prime} 04.69^{\prime \prime} \mathrm{N} 24^{\circ} 31^{\prime} 37.87^{\prime \prime} \mathrm{E}\right.$; reg. 33015; leg. P. Grootaert; MS name Plat5), mid leg in position AB42406125 was extracted for DNA. A COI barcode can be found in GenBank with accession number: KJ768329.

\section{Description}

\section{Male}

LeNGTH. Body $2.4 \mathrm{~mm}$; wing $2.7 \mathrm{~mm}$.
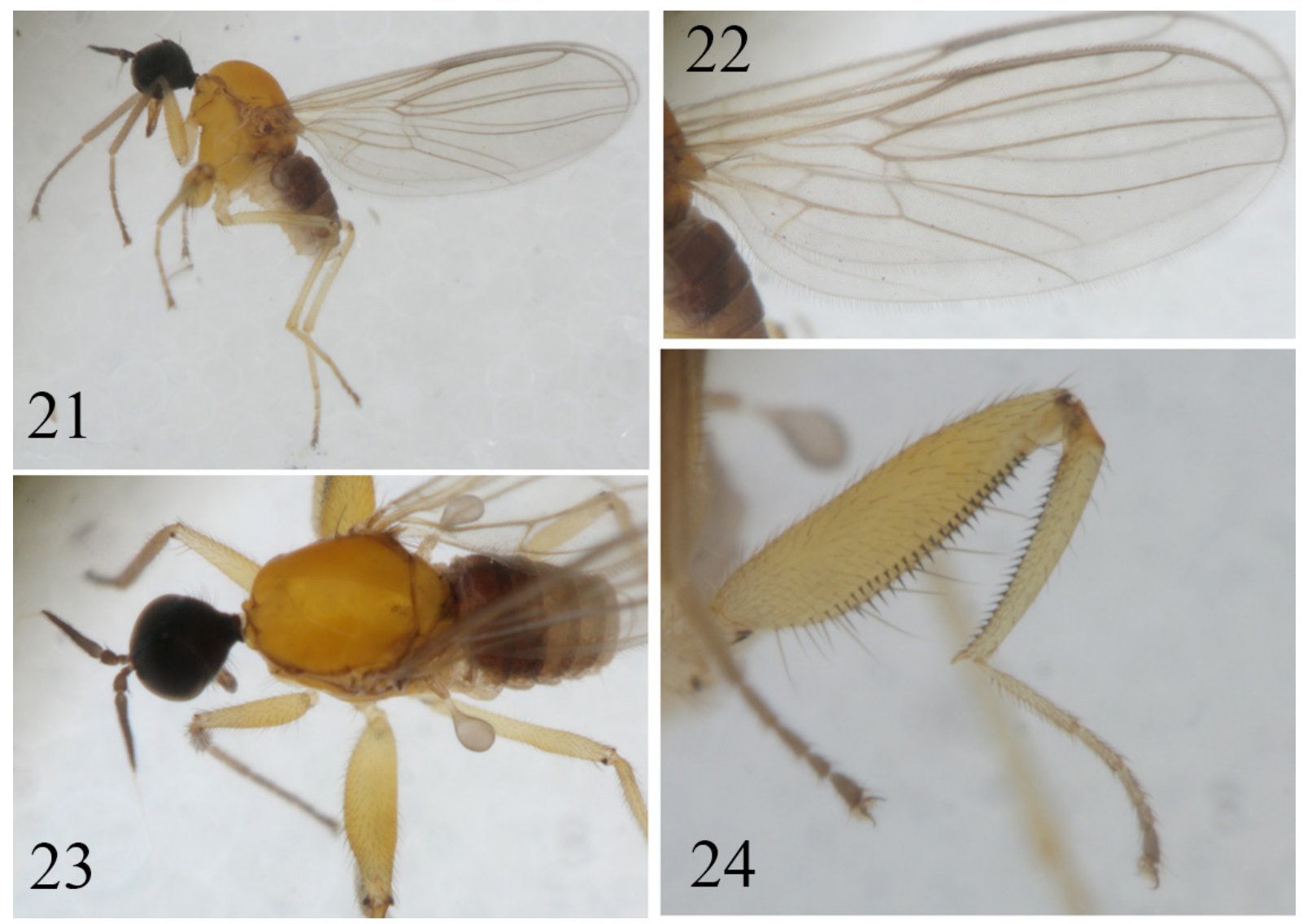

Figs 21-24. Platypalpus manjano sp. nov., holotype $\overbrace{}^{\lambda}$. 21. Habitus, lateral view. 22. Wing. 23. Head and thorax, dorsal view. 24. Mid leg, anterior view. 
HEAD. Entirely black. Occiput greyish pollinose; with 1 pair of long black verticals. Ocellar tubercle greyish pollinose, with 2 black, short anterior and 2 minute posterior setae. Frons very narrow, somewhat widened toward ocellar tubercle, above antennae nearly as broad as anterior ocellus, greyish pollinose. Face very narrow, narrower than anterior ocellus, greyish pollinose, clypeus subshining. Antenna with scape, pedicel and postpedicel brown; postpedicel conical, long, 5.3 times as long as wide; stylus white (except basal segment), long pubescent, about as long as postpedicel. Proboscis brownish, long, nearly as long as head is high. Palpus yellow, small, ovate, with scattered setulae and a long brownish subapical seta.

Thorax. Almost entirely yellow, only postpronotal lobe, notopleuron narrowly along lower margin, anepisternum (= mesopleuron) narrowly along upper margin and anterior spiracle yellowish brown; scutum shining, otherwise thorax subshining; bristles brownish. Postpronotal lobe elongate narrow, with 1 minute seta. Mesonotum with 2 notopleurals (anterior seta very short, posterior seta long, strong), 1 long strong postalar and 4 scutellars (apical pair long and cruciate, lateral pair very short); acrostichals very short, scattered, arranged in 2 broadly spaced rows; dorsocentrals uniserial, sparse, nearly as long as acrostichals, 2 prescutellar pairs somewhat longer.

Legs. Almost entirely yellow, except for fore tibia and apical four tarsomeres more brownish than fore femur; mid and hind leg with only apical tarsomere brownish. Coxae and trochanters with ordinary yellowish to brownish setae of different lengths. Fore femur slender; with very short anteroventrals and 4 fine moderately long brownish posteroventral setae on about basal half. Fore tibia slender, clothed with ordinary setulae. Mid femur very thickened; with double row of black ventral spinules and row of long, black posteroventral setae (Fig. 24). Mid tibia bearing a row of black ventral spinules; with very short flattened apical spur. Hind femur slender, with short anteroventral setae. Hind tibia slender, clothed with ordinary setulae. Tarsi of all legs unmodified.

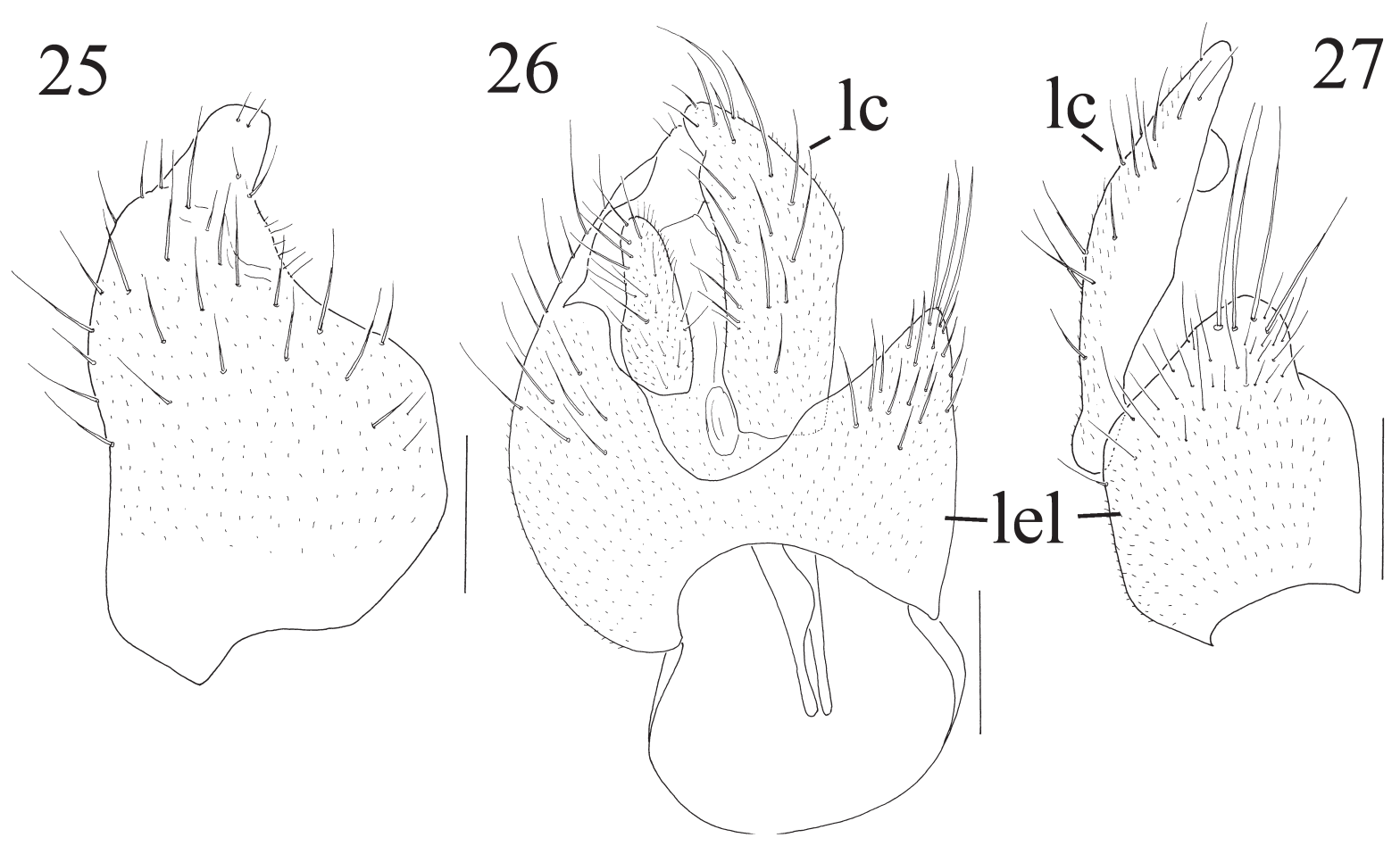

Figs 25-27. Platypalpus manjano sp. nov., holotype $\widehat{\jmath}$. 25. Right epandrial lamella. 26. Epandrium with cerci, dorsal view. 27. Left epandrial lamella. Scale bars $=0.1 \mathrm{~mm}$. 
Wing. (Fig. 22) Finely, uniformly infuscate, with brownish veins. Costa between $\mathrm{R}_{1}$ and $\mathrm{R}_{2+3}$ darkened. One moderately long costal seta. Veins $\mathrm{R}_{4+5}$ and $\mathrm{M}_{1+2}$ almost parallel just before meeting wing margin. Crossveins $\mathrm{m}$-cu and r-m contiguous; cell bm longer and distinctly broader than cell br; Vein $\mathrm{CuA}_{2}$ somewhat sinuate reaching wing border. Anal vein distinct in apical part and evanescent in basal part. Calypter brown, with about 10 brown setae. Halter darkened.

ABDOMEN. With brownish tergites and yellowish sternites (except segment 8); tergites covered with short brownish setae; sternites with similar but somewhat longer setae; segment 8 bearing numerous very long black strong setae. Terminalia (Figs 25-27) moderately large, brown. Left cercus (Fig. 26) much longer and broader than right cercus, clothed with long unmodified setae. Left epandrial lamella much shorter than right epandrial lamella bearing about 4 long apical setae.

\section{Female}

Unknown.

\section{Comparison}

In Smith's (1969) key the new species runs to P. rhodesiensis Smith, 1969 that was described from females found in Rhodes-Inyanya National Park in Zimbabwe. However the latter has scape and pedicel yellow. In P. manjano sp. nov. the scape and pedicel are brown. In P. rhodesiensis the scutellum is reddish yellow, but blackish on disc and sometimes completely black. In the new species the scutellum is yellow.

\section{Distribution}

DR Congo.

$$
\begin{aligned}
& \text { Platypalpus saffradi sp. nov. } \\
& \text { urn:Isid:zoobank.org:act:3DFF850A-3BF1-4855-8109-CD7C5BC60696 }
\end{aligned}
$$

Figs $28-31$

\section{Diagnosis}

A medium-sized yellow species of the minutus-group with thorax and legs yellow, but all coxae white; abdomen with tergites 1-5 brownish. No postpronotal (= humeral) seta present. One pair of vertical bristles. Scape and pedicel black; postpedicel brown, 2.5 times as long as broad; stylus brown. Mid tibia with long, but blunt apical spur.

\section{Etymology}

The word 'saffradi' means yellow in Swahili language and it refers to the yellow body colour of the new species.

\section{Type material}

\section{Holotype}

ㅇ, DR Congo, Yangambi, 26 May 2013, primary mixed forest MIX4 (reg. 33007, leg P. Grootaert; MS name Plat6).

\section{Paratype}

1 q, DR Congo, 4 Jun. 2013, mixed primary forest MIX3, sweeping $\left(0^{\circ} 47^{\prime} 12.80^{\prime \prime} \mathrm{N} 24^{\circ} 31^{\prime} 24.85^{\prime \prime} \mathrm{E}\right.$; reg. 33040; leg. P. Grootaert) (RBINS), mid leg extracted for DNA in tube with position code AB42406119. 


\section{Description}

\section{Female}

Length. Body $2.8 \mathrm{~mm}$; wing $2.8 \mathrm{~mm}$.

HEAD. Entirely black. Occiput densely greyish pollinose; with 1 pair of long black verticals. Ocellar tubercle greyish pollinose, with 2 black, very short anterior and 2 minute posterior setae. Frons narrow, parallel-sided, above antennae nearly 1.5 times as broad as anterior ocellus, greyish pollinose. Face very narrow, on middle narrower than anterior ocellus, somewhat broader below antennae and on lower part, greyish pollinose, clypeus subshining. Antenna (Fig. 30) with scape and pedicel black, postpedicel and stylus brownish; postpedicel conical, 3 times as long as wide; stylus 1.5 times as long as postpedicel. Proboscis brownish yellow, rather long, somewhat shorter than head is high. Palpus (Fig. 29) yellow, small, ovate, with scattered pale setulae.

THorax. (Figs 29, 30). Almost entirely reddish yellow, only metanotum brownish yellow; posterior spiracle brownish; postpronotal lobe, scutum behind postpronotal lobe, notopleuron and scutellum with some tomentosity; otherwise scutum shining, entire pleuron subshining; bristles brown. Postpronotal lobe elongate ovate, with several minute setulae. Mesonotum with 2 notopleurals (anterior seta very short, posterior seta moderately long), 1-2 moderately long postalars and 4 scutellars (apical pair long and cruciate, lateral pair very short); additionally, notopleuron with several setulae; acrostichals short,
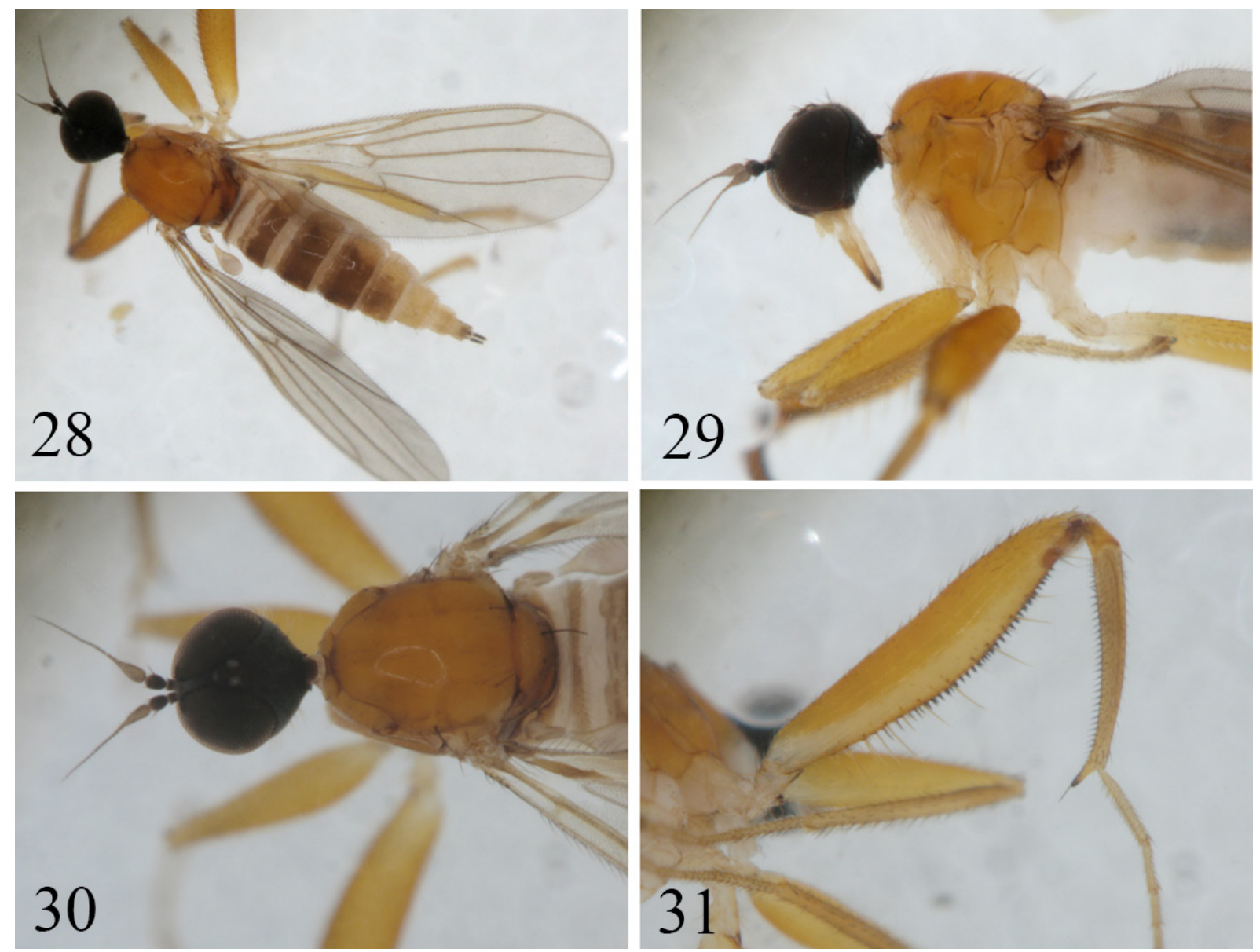

Figs 28-31. Platypalpus saffradi sp. nov., holotype ${ }^{\text {. 28. }}$. Habitus, dorsal view. 29. Head and thorax, lateral view. 30. Head and thorax, dorsal view. 31. Mid leg, anterior view. 
arranged in 2 narrow irregular rows, lacking on prescutellar depression; dorsocentrals arranged in 1-2 rows, nearly as long as acrostichals, 2 prescutellars somewhat longer.

Legs. Almost entirely yellow, only last tarsomere brownish yellow. Coxae and trochanters almost white, with ordinary yellowish to brownish yellow setae of different lengths. Fore femur thickened; with uniformly very short anteroventral and posteroventral setae. Fore tibia slender, clothed with ordinary setulae somewhat longer dorsally. Mid femur (Fig. 31) very thickened, long; with double row of black ventral spinules and row of long, yellow posteroventral setae, longest near middle as long as femur is wide. Mid tibia bearing a row of black ventral spinules; with long blunt-tipped apical spur bearing short seta. Hind femur slender, with short anteroventral setae. Hind tibia slender, clothed with ordinary setulae. Tarsi of all legs unmodified.

WING. Finely, uniformly infuscate, with brownish veins. One moderately long costal seta. Veins $\mathrm{R}_{4+5}$ and $\mathrm{M}_{1+2}$ parallel just before meeting wing margin. Crossveins $\mathrm{m}-\mathrm{cu}$ and $\mathrm{r}-\mathrm{m}$ narrowly separated; cell bm longer and distinctly broader than cell br; Vein $\mathrm{CuA}_{2}$ recurrent, somewhat sinuate. Anal vein distinct in apical part and evanescent in basal part. Calypter darkened, with brown setae. Halter darkened.

ABdomen. With tergites 1-5 brownish, tergites 6-8 brownish yellow, subshining, covered with short brownish setae; sternites yellowish to brownish yellow, sternite 8 darker; with scattered short setae; cercus slender, brown.

\section{Male \\ Unknown.}

\section{Comparison}

In the key of Smith (1969), P. saffradi sp. nov. runs to P. eshowensis Smith, 1969 described from Zululand (South Africa). In the latter species the frons is wider (2.5 times ocellar width), face below antenna about 1.5 times ocellus and there is a distinct fine humeral seta. In P. saffradi sp. nov. the frons is narrower (only 1.5 times the width of anterior ocellus), face is almost linear and there is no distinct humeral seta. Platypalpus eshowensis has a long sharp apical spur on mid tibia, while it is long, but blunt in P. saffradi sp. nov. with a black bristle at tip. Finally the apical two tarsomeres of all legs are darkened while in P. saffradi sp. nov. only the apical half of the apical tarsomere is brownish.

Platypalpus saffradi sp. nov. is provisionally placed in the minutus-group because of the presence of a well-developed postpronotal lobe lacking however a distinct postpronotal seta. Mesonotum is polished and mid tibia bears a long apical spur.

\section{Distribution}

DR Congo.

$$
\begin{gathered}
\text { Platypalpus yangambensis sp. nov. } \\
\text { urn:lsid:zoobank.org:act:C6BF7E87-A8E1-4D0E-8EC0-65366CAEBC2F }
\end{gathered}
$$

Figs 32-38

\section{Diagnosis}

A medium-sized black species of the minutus-group with two pairs of indistinct vertical bristles. Scutum shining black; pleura brownish black dusted but katepisternum largely polished. Legs yellow but mid femur with narrow ventral brown stripe that is shortly interrupted near middle and hind femur a black ring in middle. Mid tibia half as long as femur, with a strong sharp spur. 


\section{Etymology}

The specific epithet refers to the type locality, Yangambi.

\section{Type material}

\section{Holotype}

7 , DR Congo, Yangambi, 27 May 2013, primary mixed forest, path to GIL4 sweeping from 9.05 am to 9.45 am (047’32.65” N 24³1’42.33” E; reg. 33010; leg. P. Grootaert; MS name Plat1).

\section{Paratypes}

$1 \delta$ from same provenance as holotype (RBINS); 1 त with same provenance as holotype in tray Entomo001 at position E4, completely extracted with barcode AB48937135 (RBINS); 1 o with same provenance as holotype with mid leg in tray Entomo004 at position A3 with barcode AB42406113 has been extracted for DNA (RBINS); 1 \%, Yangambi, 26 May 2013, primary mixed forest, MIX4 (047'12.80” N 24³1'24.85” E; reg. 33007; leg. P. Grootaert) (RBINS); 1 ð, Yangambi, 27 May 2013 , primary mixed forest, sweeping along path to MIX4 from 2.15 pm to $3.05 \mathrm{pm}\left(0^{\circ} 48^{\prime} 04.69^{\prime \prime} \mathrm{N}\right.$ $24^{\circ} 31^{\prime} 37.87^{\prime \prime}$ E; reg. 33015, leg. P. Grootaert) male completely extracted in tray Entomo001 at position E3 with barcode AB48937141 (RBINS). The COI barcodes are available in GenBank with accession numbers: KJ768330, KJ768331 and KJ768332.
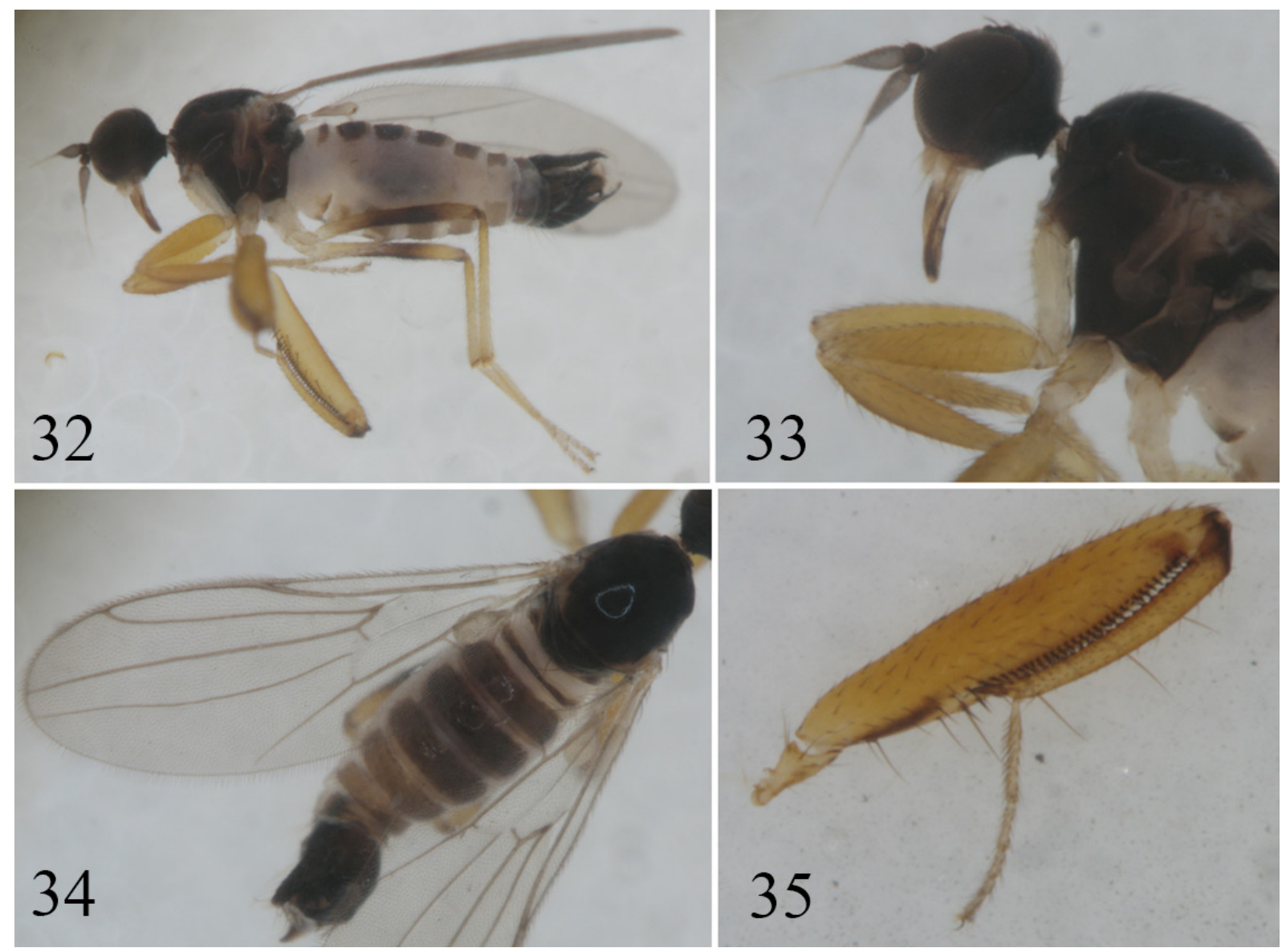

Figs 32-35. Platypalpus yangambensis sp. nov., paratype $\widehat{\jmath}$. 32. Habitus, lateral view. 33. Head and thorax, lateral view. 34. Wing. 35. Mid leg, anterior view. 


\section{Description}

\section{Male}

Length. Body $3.0 \mathrm{~mm}$; wing $2.4 \mathrm{~mm}$.

HEAD. Entirely black in ground-colour. Occiput entirely faintly greyish pollinose; with 2 pairs of dark very short verticals (hardly distinguished from other occipital setae), further clothed with short bristly hairs, longer setae on lower part. Ocellar tubercle greyish pollinose, with 2 dark, short anterior and 2 minute posterior setae. Frons widened toward ocellar tubercle, above antennae nearly 1.5 times as broad as anterior ocellus, shining. Face narrow, greyish pollinose, clypeus subshining. Antenna (Fig. 33) with scape and pedicel black, postpedicel brown; postpedicel conical, about 3.0 times as long as wide; stylus dirty white, nearly 1.5 times as long as postpedicel. Proboscis brownish, long, nearly as long as head is high. Palpus (Fig. 33) yellow, ovate, short, with scattered setulae and a long, brown subapical seta.

THORAX. (Fig. 33). Largely brown, postalar ridge yellow, anepisternum (= mesopleuron) along posterior margin, katepisternum (= sternopleuron) on upper posterior corner and anepimeron (= pteropleuron) and meron (= hypopleuron) yellowish brown; scutum (except notopleural depression) shining, sternopleuron with large shining spot; long bristles brownish. Postpronotal lobe moderately large, with 1 short, fine seta and several setulae. Mesonotum with 2 notopleurals (posterior longer), 1 short postalar and 4 scutellars (apical pair long and cruciate, lateral pair very short); acrostichals very short, arranged in 2 almost regular, very broadly spaced rows; dorsocentrals uniserial, nearly as long as acrostichals.

LEGS. Almost entirely yellow; fore and hind coxae and trochanters almost white; mid coxae yellowish; mid femur with narrow ventral brown stripe (interrupted before middle), hind femur with broad brownish ring on apical part leaving narrow subapical space yellow, knees of mid and hind legs brownish. Coxae and trochanters with ordinary yellowish to brownish setae of different lengths. Fore femur moderately thickened, with minute pale brown anteroventral and posteroventral setae; a strong brown posterior seta near base of femur. Fore tibia very thickened, spindle-shaped, clothed with ordinary setulae. Mid femur

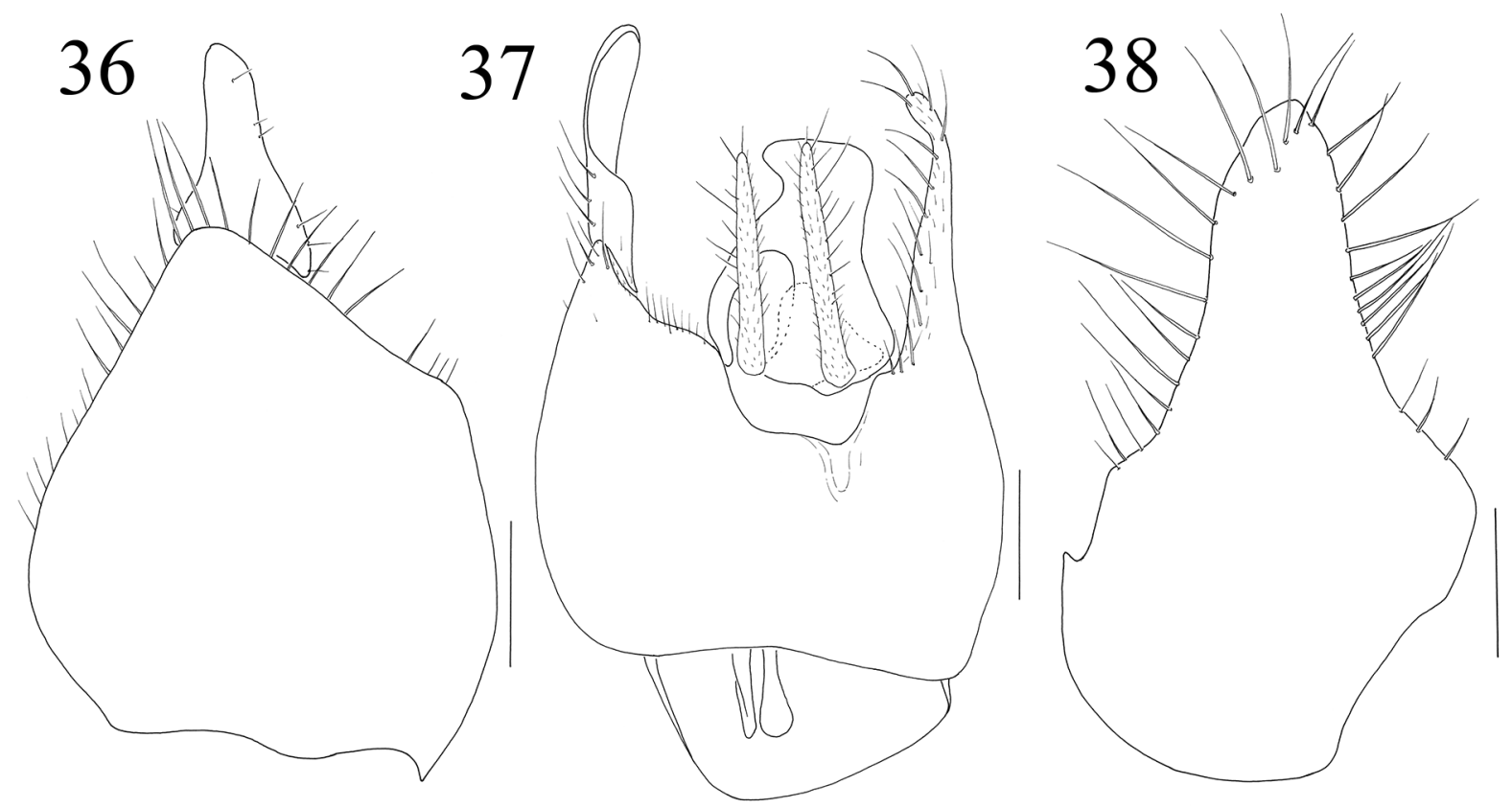

Figs 36-38. Platypalpus yangambensis sp. nov., paratype $ð$. 36. Right epandrial lamella. 37. Epandrium with cerci, dorsal view. 38. Left epandrial lamella. Scale bars $=0.1 \mathrm{~mm}$. 
(Fig. 35) about 1.5 times stouter and almost twice longer than fore femur; with double row of black ventral spinules and row of long, brown posteroventral setae. Mid tibia about half as long as femur, with long pointed apical spur bearing 2 subapical setulae of different lengths. Hind femur slender, with short anteroventral setae. Hind tibia slender, clothed with ordinary setulae. Tarsi of all legs unmodified.

WING. (Fig. 34). Finely, uniformly faintly infuscate, with brownish veins. One short black costal seta. Veins $\mathrm{R}_{4+5}$ and $\mathrm{M}_{1+2}$ convergent just before meeting wing margin. Crossveins $\mathrm{m}$-cu and $\mathrm{r}-\mathrm{m}$ separated; bm longer and slightly broader than br. Vein $\mathrm{CuA}_{2}$ somewhat sinuate, not recurrent. Anal vein distinct in apical part and evanescent in basal part. Calypter brown, with brown setae. Halter darkened.

Aвdomen. With tergites brown, subshining, covered with very short setae; sternites somewhat paler, with similar setation; segment 8 with several moderately long yellowish brown posteromarginal setae. Terminalia (Figs 32, 36-38) moderately large, brown. Both cerci equally long, fine digitiform, not protruding from epandrial lamellae. Right and left epandrial lamellae equally long.

\section{Female}

Palpus elongate, about half as long as labrum, pointed. Fore tibia almost slender, somewhat stouter basally. Abdomen with tergites 1-5 brown, subshining, covered with scattered setulae, tergites 6-8 paler, sternites pale; cercus narrow, brownish.

\section{Comparison}

This species does not resemble any of Smith's species (1967a, 1967b, 1969). It might be compared with P. gracilipes Smith, 1967 described from Tanzania (Smith 1967a) but in the latter the proboscis is short, less than half head height while in the new species the proboscis is as long as head is high.

\section{Distribution}

DR Congo.

\section{Key to Platypalpus of DR Congo}

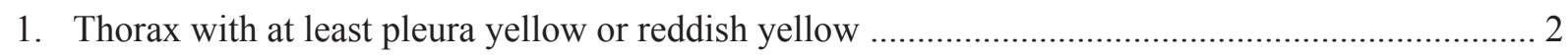

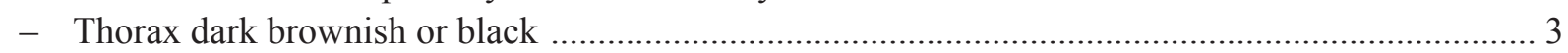

2. Stylus white (albiseta-group) with postpedicel 5.3 times as long as broad; mid tibia with pointed apical spur shorter than tibia is wide

.P. manjano sp. nov.

- Stylus brown with postpedicel 2.5 times as long as broad; mid tibia with long blunt apical spur longer than tibia is wide P. saffradi sp. nov.

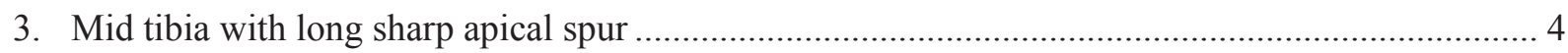

- Apical spur on mid tibia shorter than tibia is wide. Species from the albiseta-group ..................... 5

4. Mid femur darkened above

P. bolikoi sp. nov.

- Mid femur yellow, ventrally with dark brown black stripe along the double row of spinules

P. yangambensis sp. nov.

5. Postpedicel 5.3 times as long as wide; stylus 1.6 times as long as postpedicel

P. ikoso sp. nov.

- Postpedicel nearly 4 times as long as wide; stylus almost 2.5 times as long as postpedicel. 


\section{Acknowledgements}

We thank Dr Erik Verheyen coordinator of RBINS's part of COBIMFO as well as Prof. Benjamin Dudu Akaibe (University of Kisangani) for their support. Further the first author thanks Mr Thierry Bouyer (RBINS), Dr Jean Lambert Wetsi Lofete (University of Kisangani) and Mr Lola Boliko (INERA) for their help in the field. Last but not least, we thank Dr Adrian Plant and Dr Andreas Stark for their many useful comments.

\section{References}

Becker T. 1914. Diptères nouveaux récoltés par MM. Ch. Alluaud et R. Jeannel en Afrique orientale 1911-1912. Annales de la Société Entomologique de France 83:120-130.

Collin J.E. 1922. Empididae from the Seychelles. The Entomologist's monthly Magazine 58: 184-189.

Engel E.O. 1939. Empididae. In: Lindner E. (ed.) Die Fliegen der palaearktischen Region. Bd. IV: 41-104. Schweizerbart'sche Verlagsbuchhandlung, Stuttgart.

Grootaert P. \& Chvála M. 1992. Monograph of the genus Platypalpus (Diptera: Empidoidea, Hybotidae) of the Mediterranean region and the Canary Islands. Acta Universitatis Carolinae - Biologica 36, Univerzita Karlova, Praha.

Grootaert P. \& Shamshev I. 2006. The genus Platypalpus Macquart (Diptera: Hybotidae) from Northeast Thailand with comments on the species groups in the Oriental region. Journal of Natural History 39 (47): 4031-4065. http://dx.doi.org/10.1080/00222930500533781

Grootaert P. \& Shamshev I.V. 2012. The fast-running flies (Diptera, Hybotidae, Tachydromiinae) of Singapore and adjacent regions. European Journal of Taxonomy 5: 1-162. http://dx.doi.org/10.5852/ ejt.2012.5

Grootaert P. \& I. Shamshev 2013. The flies of the family Hybotidae (Diptera, Empidoidea) collected during the Boyekoli Ebale Congo 2010 Expedition in Democratic Republic of Congo. Zootaxa 3603: 1-61. http://dx.doi.org/10.11646/zootaxa.3603.1.1

International Commission on Zoological Nomenclature (ICZN) 1963. Opinion 678. The suppression under the plenary powers of the pamphlet published by Meigen, 1800. Bulletin of Zoological Nomenclature 20: 339-342.

Loew H. 1858. Bidrag till kännedomen om Afrikas Diptera. Öfversigt af Kongliga Vetenskaps-Akademiens Förhandlingar 14 (9): 337-383.

Macquart J. 1827. Insectes diptères du nord de la France. Vol. 3. Platypézines, dolichopodes, empides, hybotides. Imprimerie de L. Danel, Lille. http://dx.doi.org/10.5962/bhl.title.8146

Meigen J.W. 1800. Nouvelle classification des mouches à deux ailes (Diptera L.) d'après un plan tout nouveau. Perronneau, Paris.

Smith K.V.G. 1967a. Chapter IX. Diptera (Brachycera): Empididae. In: Hanström B., Brinck P. \& Rudebeck G. (eds) South African animal life: results of the Lund University Expedition in 1950-1951. Vol. 13: 215-233. Almqvist \& Wiksell, Stockholm.

Smith K.G.V. 1967b. Afrikanische Empididae (Dipt.). Stuttgarter Beiträge zur Naturkunde 179: 1-16.

Smith K.V.G. 1969. The Empididae of southern Africa (Diptera). Annals of the Natal Museum 19, Natal Museum, Pietermaritzburg.

Westwood J.O. 1840. Order XIII. Diptera Aristotle. (Antliata Fabricius. Halteriptera Clairv.). In: Westwood J.O. (ed.) An introduction to the modern classification of insects; founded on the natural habits and corresponding organisation of the different families. Vol. 2. Synopsis of the genera of British 
insects: 125-154. Longman, Orme, Brown, Green and Longmans, London. http://dx.doi.org/10.5962/ bhl.title. 12455

Yang D., Zhang K., Yao G. \& Zhang J. 2007. World Catalog of Empididae (Insecta: Diptera). China Agricultural University Press, Beijing.

Manuscript received: 3 February 2014

Manuscript accepted: 29 August 2014

Published on: 25 November 2014

Topic editor: Koen Martens

Desk editor: Charlotte Thionois

Printed versions of all papers are also deposited in the libraries of the institutes that are members of the EJT consortium: Muséum national d'Histoire naturelle, Paris, France; Botanic Garden Meise, Belgium; Royal Museum for Central Africa, Tervuren, Belgium; Natural History Museum, London, United Kingdom; Royal Belgian Institute of Natural Sciences, Brussels, Belgium; Natural History Museum of Denmark, Copenhagen, Denmark. 